\title{
PERAN KOMISARIS INDEPENDEN DI INDONESIA: MULTINATIONALITY, TAX HAVEN, PENGHINDARAN PAJAK
}

\author{
Tania Alvianita Pramudya ${ }^{1}$; Chyntia Lie ${ }^{2}$; Amrie Firmansyah ${ }^{3)}$; Estralita Trisnawati ${ }^{4)}$ \\ 1) alvianitania.1412@gmail.com, Magister Akuntansi Universitas Tarumanagara \\ 2) chyntialie97@gmail.com, Magister Akuntansi Universitas Tarumanagara \\ 3)amrie@pknstan.ac.id, Politeknik Keuangan Negara STAN \\ 4)estralitat@fe.untar.ac.id, Magister Akuntansi Universitas Tarumanagara
}

\begin{abstract}
This study aims to examine the effect of multinationality and tax havens on tax avoidance. In addition, this study also includes an independent commissioner as a moderator in the relationship between the independent and dependent variables. This study uses data from companies in the consumer goods industry from 2017 to 2019 sourced from www.idx.co.id. Based on purposive sampling, the final sample of this study amounted to 64 observations. The analytical method used in this study is multiple linear regression analysis for panel data. The results show that multinationality has a positive effect on tax avoidance, while tax havens have a negative effect on tax avoidance. Meanwhile, the independent committee did not succeed in having a role in the relationship between multinationality and tax avoidance and tax havens and tax avoidance. This study indicates a need for coordination between the Indonesian Tax Authority and Indonesian Capital Market Supervisory Authority related to strengthening the role of independent commissioners in the supervisory function of issuer companies.

Keywords: Multinationality, Tax Haven, Tax Avoidance, Independent Commissioner
\end{abstract}

\begin{abstract}
Abstrak
Penelitian ini bertujuan untuk menguji pengaruh multinationality dan tax haven terhadap penghindaran pajak. Selain itu, penelitian ini juga memasukkan komisaris independen sebagai pemoderasi daalam hubungan variabel independen dan dependen. Penelitian ini menggunakan data perusahaan sektor industri barang konsumsi tahun 2017 sampai dengan 2019 yang bersumber dari www.idx.co.id. Berdasarkan purposive sampling, sampel final penelitian ini berjumlah 64 observasi. Metode analisis yang digunakan dalam penelitian ini adalah analisis regresi linier berganda untuk data panel. Hasil penelitian menunjukkan bahwa multinationality berpengaruh positif terhadap tax avoidance, sedangkan tax haven berpengaruh negatif terhadap penghindaran pajak. Sementara itu, komite independen tidak berhasil memiliki peran dalam hubungan multinationality dan penghindaran pajak maupun hubungan tax haven terhadap penghindaran pajak. Penelitian ini mengindikasikan bahwa perlu adanya koordinasi antara Otoritas Perpajakan Indonesia dan Otoritas Pengawas Pasar Modal Indonesia terkait dengan penguatan peran komisaris independen dalam fungsi pengawasan kepada perusahaan emiten.

Kata Kunci: Multinationality, Tax Haven, Penghindaran Pajak, Komisaris Independen
\end{abstract}

\section{PENDAHULUAN}

Sebelum terjadinya pandemi covid 19, pemerintah mencatat penerimaan pajak yang selalu meningkat selama periode tahun 2017 sampai dengan tahun 2019 (Kemenkeu, 2020). Penerimaan perpajakan merupakan sumber penerimaan negara yang terbesar di dalam Anggaran Pendapatan dan Belanja Negara (Badan Pusat Statistik, 2021). Kewajiban perpajakan yang dikenakan pemerintah tidak selalu direspon baik oleh wajib pajak. Adanya indikasi penghindaran pajak yang dilakukan oleh wajib pajak dengan merencanakan pajak yang dilakukan secara legal atau masih sesuai dengan ketentuan peraturan perundang-undangan perpajakan (Irawan et al., 2020), masih menjadi isu yang terjadi saat ini. Dalam konteks perencanaan pajak, perusahaan perusahaan multinasional memiliki potensi untuk melakukan penghindaran pajak karena perusahan tersebut beroperasi di beberapa negara (Widodo et al., 2020).

Otoritas Perpajakan Indonesia menyatakan terdapat adanya penghindaran pajak hingga Rp 68,7 triliun per tahun yang mengakibatkan Indonesia diperkirakan rugi hingga US\$ 4,86 miliar per 


\section{JURNALKU}

Volume 1 No. 3, September 2021

tahun (Pajakku, 2020). Penghindaran pajak yang dilakukan oleh perusahaan multinasional terjadi akibat transaksi-transaksi yang terjadi antara pihak yang mempunyai hubungan instimewa baik di dalam negeri maupun luar negeri (Irawan \& Safitri, 2021). Perusahaan multinasional mengalihkan laba operasinya ke negara yang memiliki tarif pajak rendah (Irawan \& Safitri, 2021).

Aktivitas penghindaran pajak yang dilakukan perusahaan dapat menurunkan penerimaan Pemerintah. Penghindaran pajak dilakukan dengan melakukan perencanaan pajak dengan memanfaatkan celah peraturan perpajakan dan standar akuntansi keuangan. Manajer memiliki informasi yang lebih sempurna dibandingkan pemilik perusahaan, sehingga aktivitas penghindaran pajak dilakukan secara sepihak oleh manajer. Manajer dapat memanfaatkan penghindaran pajak untuk memenuhi motif tertentu. Oleh karena itu, ulasan penghindaran pajak perlu dielaborasi lebih lanjut.

Pengujian penghindaran pajak di Indonesia telah diidentifikasi oleh Arham et al. (2020) dengan menggunakan 105 artikel yang terindeks Sinta dan Scopus selama tahun 1999 sampai dengan tahun 2019 di antaranya penelitian yang dilakukan oleh Andawiyah et al. (2019), Aryotama \& Firmansyah (2019), Dwiyanti \& Jati (2019), Fadhila \& Handayani (2019), Fitria \& Handayani (2019), Prastiwi \& Ratnasari (2019), Purbowati \& Yuliansari (2019), Sumunar et al. (2019). Selanjutnya, penelitian penghindaran pajak di Indonesia dilakukan oleh Falbo \& Firmansyah (2021), Firmansyah \& Triastie (2020), Laksono \& Firmansyah (2020), Puspitasari et al. (2021), Widodo et al. (2020) dan Wijaya \& Rahayu (2021).

Penelitian ini bertujuan untuk menguji pengaruh multinationality dan tax haven tehadap penghindaran pajak. Banyaknya penghindaran pajak oleh perusahaan multinasional tentunya akan menghambat kestabilan pertumbuhan ekonomi negara-negara berkembang termasuk Indonesia. Perusahaan multinasional menerapkan perencanaan pajak yang memungkinkan anak perusahaannya mendapat penghasilan dari luar negeri, sehingga perusahaan multinasional dapat melakukan penghindaran pajak dengan jumlah yang lebih besar (Taylor \& Richardson, 2012). Hanlon et al. (2007) menyatakan bahwa perusahaan yang menjadi bagian dari perusahaan asing melakukan penghindaran pajak lebih besar dibandingkan dengan perusahaan domestik..

Pada umumnya, perusahaan melakukan pengalihan pendapatan ke perusahaannya yang berada di negara suaka pajak atau tax haven country. Negara suaka pajak merupakan suatu negara yang dijadikan 'tempat berlindung' oleh wajib pajak (Febrantara, 2021). OECD menetapkan 4 kriteria tax haven country yaitu, adanya tarif pajak yang rendah atau tidak sama sekali, tidak adanya transparansi dalam pemungutan pajak, tidak adanya pertukaran informasi, dan tidak adanya persyaratan aktivitas substansial bagi perusahaan (OECD, 1998). Tax Justice Network menguraikani negara-negara suaka pajak untuk perusahaan multinasional berdasarkan tingkat agresifitas dan kontribusi negara dalam membantu perusahaan multinasional agar terhindar dari membayar pajak (DTCC, 2019).

Penelitian Sima (2018), Widodo et al. (2020) menguji multinationality dan tax haven terhadap penghindaran pajak, Falbo \& Firmansyah (2021) menguji multinationility terhadap penghindaran pajak, Wijaya \& Rahayu (2021) menguji tax haven terhadap penghindaran pajak. Dalam penelitian ini selain menguji multinationality dan tax haven terhadap penghindaran pajak, juga memasukkan komisaris independen sebagai variabel moderasi. Peran komisaris independen dalam mengawasi perilaku manajer dalam aktivitas operasi sangat diperlukan dalam meningkatkan tata kelola perusahaan. Komisaris independen diharapkan dapat mendisplinkan perilaku manajer termasuk aktivitas penghindaran pajak. Pengawasan yang semakin baik kepada manajemen dapat meningkatkan tata kelola perusahaan (Armstrong et al., 2015; Richardson et al., 2013). Armstrong et al. (2015) dan Richardson et al. (2013) membuktikan bahwa kehadiran komisaris independen 


\section{JURNALKU}

Volume 1 No. 3, September 2021

dapat menurunkan penghindaran pajak yang agresif. Oleh karena itu, komisaris independen diharapkan memiliki peran pengawasan atas aktivitas manajer dalam operasi perusahaan.

\section{KAJIAN LITERATUR}

Watts \& Zimmerman (1990) menyampaikan hipotesis biaya politik yang menjelaskan bahwa perusahaan dengan profitabilitas tinggi akan menggeser pendapatannya dari periode sekarang ke periode mendatang untuk menghindari adanya biaya politik. Penghindaran pajak terjadi karena manajer menggeser laba perusahaan untuk menghindari adanya biaya pajak yang tinggi. Perusahaan multinasional dengan menggeser labanya dari negara asalnya ke negara cabangnya yang memiliki tarif pajak lebih rendah atau bahkan nol (tax haven country). Perusahaan dengan laba tinggi cenderung akan menggeser labanya untuk menghindari adanya biaya politik.

Peningkatan transaksi multinationality diikuti dengan menurunnya tingkat agresivitas pajak (meningkatnya ETR) perusahaan (Damayanti \& Prastiwi, 2017). Perusahaan multinasional umumnya memiliki banyak cabang di negara-negara sesuai dengan pangsa pasar produksinya. Pendirian cabang perusahaan yang dilakukan oleh perusahaan multinasional bertujuan untuk memperkuat basis perusahaan secara global (Widodo et al., 2020). Banyaknya perusahaan cabang di luar negeri yang dimiliki oleh perusahaan multinasional mendorong perusahaan tersebut untuk melakukan penghindaran pajak (Sima, 2018). Manajer perusahaan multinasional berusaha untuk melakukan multinationality untuk memperluas pangsa pasar ataupun memperkuat aliansi perdagangan. Tindakan tersebut memungkinkan adanya praktik penghindaran pajak dalam transaksi antara perusahaan induk dan cabangnya yang terdapat di negara lain.

\section{H1: Multinationality berpengaruh positif terhadap penghindaran pajak}

Manajer di dalam perusahaan multinasional selalu berupaya untuk memanfaatkan lokasi usaha di negara tax haven dalam rangka untuk menurunkan kewajiban perpajakan. Sianipar (2020) menyimpulkan bahwa adanya konflik kepentingan dalam menghasilkan keputusan terkait dengan keuntungan perusahaan yang maksimal, salah satunya dilakukan dengan cara memiliki cabang perusahaan di negara dengan regulasi pajak yang sangat rendah atau bahkan tidak dikenakan pajak sama sekali. Negara yang dengan sengaja menerapkan regulasi pajak yang sangat rendah dalam bentuk pengenaan tarif yang rendah atau bahkan tidak dikenakan pajak sama sekali bertujuan untuk memberikan fasilitas pajak yang mudah bagi investor yang berasal dari luar negara tersebut (Widodo et al., 2020). Manajer selaku agen memilih untuk membuka cabang di negara yang menurutnya merupakan pangsa pasar yang besar, walaupun manajer juga harus memikirkan mengenai biaya-biasa dalam membuka cabang salah satunya adalah biaya politik. Biaya tersebut tentunya dapat dikompensasi dengan penghematan pajak yang dihasilkan dari penghindaran pajak yang dilakukan oleh manajer. Oleh karena itu, perusahaan tentunya ingin menekan biaya pajak perusahaan dengan memanfaatkan adanya tax haven country.

\section{$\mathrm{H}_{2}$ : Tax haven berpengaruh positif terhadap penghindaran pajak}

Menurut Jensen \& Meckling (1976), asimetri informasi terjadi ketika manajer memiliki lebih banyak informasi dibandingkan pemilik perusahaan. Manajer yang mengusahakan melakukan penghindaran pajak merupakan hal yang menguntungkan bagi perusahaan. Namun apabila tindakan penghindaran pajak dilakukan secara agresif tentunya akan menyebabkan perusahaan mengalami kerugian akibat adanya potensi denda pajak di masa mendatang. Untuk meminimalisir tindakan penghindaran pajak yang agresif, diperlukan pengawasan atas tindakan manajer dalam aktivitas perusahaan. Eksandy (2017) menyatakan bahwa dengan pengawasan yang semakin besar, manajemen akan berhati-hati dalam mengambil keputusan dan transparan dalam menjalankan perusahaan sehingga tindakan penghindaran pajak dapat diminimalkan. Richardson et al. (2013) 


\section{JURNALKU}

Volume 1 No. 3, September 2021

menemukan bahwa komisaris independen dapat menurunkan penghindaran pajak yang agresif yang dilakukan oleh manajer.

Kehadiran komisaris independen dapat menekan perilaku manajer dalam melakukan penghindaran pajak melalui tindakan multinationality, khususnya untuk perusahaan multinasional. Komisaris independen berusaha untuk menyelaraskan tindakan manajer dengan keinginan pemegang saham. Walaupun tindakan penghindaran pajak tidak melanggar ketentuan hukum, namun potensi denda pajak di masa mendatang selalu tetap ada. Selain itu, tindakan penghindaran pajak yang dilakukan oleh manajer dengan motif tertentu dapat merugikan pemegang saham.

H3: Komisaris independen memperlemah pengaruh positif multinationality terhadap penghindaran pajak

Adanya informasi asimetri antara manajer dan pemegang saham, mengakibatkan manajer melakukan tindakan yang tidak sesuai dengan keinginan pemegang saham (Firmansyah, Jadi, et al., 2021). Fungsi pengawasan diperlukan dalam menyelaraskan kepentingan manajer dan pemegang saham. Armstrong et al. (2015) membuktikan bahwa pengawasan yang dilakukan oleh komisaris independen dapat menekan tindakan penghindaran pajak yang dilakukan oleh manajer.

Manajer dalam perusahaan multinasional cenderung untuk mengalihkan laba di negaranya ke negara dengan tarif pajak rendah atau bahkan tidak ada sama sekali. Namun, dewan komisaris selaku pengawas berusaha untuk meminimalisir transaksi yang mengarah pada tindakan penghindaran pajak. Kehadiran komisaris independen mengakibatkan manajer dalam perusahaan multionasional tetap memperhatikan kepentingan seluruh pemegang saham.

\section{H4: Komisaris independen memperlemah pengaruh positif tax haven terhadap penghindaran pajak}

\section{METODE}

Penelitian ini menggunakan data sekunder berupa data yang bersumber dari laporan tahunan dari sektor industri barang konsumsi yang diperoleh dari Bursa Efek Indonesia (BEI) yang diunduh melalui website www.idx.co.id. Berdasarkan purposive sampling, kriteria sampel penelitian ini adalah sebagai berikut:

Tabel 1 Sampel Penelitian

\begin{tabular}{lcc}
\hline \multicolumn{1}{c}{ Kriteria } & Jumlah & Ukuran \\
\hline $\begin{array}{l}\text { Perusahaan sektor industri barang konsumsi yang terdaftar di BEI 2017-2019 } \\
\text { per Maret 2021 }\end{array}$ & 64 & Perusahaan \\
Perusahaan dengan Laporan Tahunan tidak lengkap selama 3 tahun & $(21)$ & Perusahaan \\
Perusahaan yang tidak memiliki komponen utk digunakan dalam variabel & $(22)$ & Perusahaan \\
penelitian & & \\
Total Perusahaan yang dapat digunakan dalam penelitian & 21 & Perusahaan \\
Jumlah Tahun & 3 & Tahun \\
Total Sampel & 63 & Observasi \\
\hline
\end{tabular}

Variabel dependen dalam penelitian ini adalah penghindaran pajak dengan menggunakan proksi effective tax rate (ETR) sesuai dengan Chen et al. (2010), Desai \& Dharmapala (2006), Hanlon \& Heitzman (2010), Puspitasari et al. (2021) sebagai berikut :

$$
\mathrm{ETR}=\frac{\text { Pembayaran pajak }}{\text { Laba sebelum pajak }}
$$

Semakin tinggi nilai ETR semakin perusahaan mematuhi kewajiban perpajakannya, seabliknya, semakin rendah nilai ETR semakin perusahaan melakukan penghindaran pajak. 


\section{JURNALKU}

Volume 1 No. 3, September 2021

Variabel independen dalam penelitian ini adalah multinationality dan tax haven. Proksi multinationality adalah apabila perusahaan memiliki cabang perusahaan di luar negeri minimal di lima negara akan dinyatakan dengan nilai 1, sedangkan apabila kurang dari lima akan dinyatakan dengan nilai 0 sebagaimana Falbo \& Firmansyah (2021), Sima (2018), Widodo et al. (2020). Sementara itu, proksi tax haven adalah apabila perusahaan memiliki setidaknya minimal dua anak usaha yang tergabung dalam tax haven diakui OECD dinyatakan 1 dan sebaliknya apabila kurang dari dua perusahaan maka dinyatakan 0 sebagaimana Taylor \& Richardson (2012), Widodo et al. (2020), Wijaya \& Rahayu (2021).

Variabel moderasi dalam penelitian ini adalah komisaris independen mengikuti proksi Firmansyah, Pamungkas, et al. (2021), Kusuma \& Firmansyah (2018), Nugroho \& Firmansyah (2018).

$$
\text { KomInd }=\frac{\text { Jumlah komisaris independen }}{\text { Total komisaris }}
$$

Penelitian ini juga menggunakan variabel kontrol yang terdiri dari arus kas operasi, profitabilitas, dan leverage. Arus kas operasi menggunakan proksi yang digunakan oleh Armstrong et al. (2015) dan Puspitasari et al. (2021) yaitu:

$$
\mathrm{OCF}=\frac{\text { Arus kas dari aktivitas operasi }}{\text { Total aset }}
$$

Profitabilitas akan diukur dengan menggunakan proksi Return on Assets (ROA) sebagaimana Falbo \& Firmansyah (2021), dan Richardson et al. (2013).

$$
\text { ROA }=\frac{\text { Laba setelah pajak }}{\text { Total Aset }}
$$

Leverage menggunakan proksi debt to equity ratio (DER) sebagaimana Puspitasari et al. (2021).

$$
\text { DER }=\frac{\text { Total utang }}{\text { Total ekuitas }}
$$

Hipotesis dalam penelitian ini diuji dengan menggunakan analisis regresi berganda dengan data panel. Adapun model penelitian ini terdiri dari 2 model, model 1 merupakan model untuk pengujian hipotesis 1 dan 2, sedangkan model 2 merupakan model untuk pengujian hipotesis 3 dan 4 .

$$
\begin{aligned}
& \mathrm{ETR}_{\text {it }}=\beta 0+\beta 1 \text { MULNAT }_{\text {it }}+\beta 2 \mathrm{THAV}_{\mathrm{it}}+\beta 30 \mathrm{CF} \mathrm{it}_{\mathrm{it}}+\beta 4 \mathrm{DER}_{\mathrm{it}}+\beta 5 \mathrm{ROA}_{\mathrm{it}}+\varepsilon_{\mathrm{it}} \\
& \text { ETR }_{\text {it }}=\beta 0+\beta 1 \text { MULNAT }_{\text {it }}+\beta 2 \text { THAV }_{\text {it }}+\beta 3 \text { KomInd }_{\text {it }}+\beta 4 \text { MULNAT } * \text { KomInd }_{\text {it }} \\
& +\beta 5 \text { THAV } * \text { KomInd }_{i t}+\beta 60 \mathrm{CF}_{\text {it }}+\beta 7 \mathrm{DER}_{\mathrm{it}}+\beta 8 \mathrm{ROA}_{\mathrm{it}}+\varepsilon_{\mathrm{it}} \ldots
\end{aligned}
$$

\section{HASIL DAN PEMBAHASAN}

Statistik deskriptif variabel yang digunakan dalam penelitian ini terdapat dalam tabel 2.

Tabel 2 Statistik Deskriptif

\begin{tabular}{cccccc}
\hline & Mean & Med. & Max. & Min. & St.Dev \\
\hline ETR & 0.267 & 0.254 & 0.480 & 0.189 & 0.045 \\
MULNAT & 0.476 & 0.000 & 1.000 & 0.000 & 0.503 \\
THAV & 0.333 & 0.000 & 1.000 & 0.000 & 0.475 \\
KomInd & 0.539 & 0.500 & 1.000 & 0.000 & 0.242 \\
OCF & 0.156 & 0.135 & 0.530 & -0.234 & 0.137 \\
DER & 0.678 & 0.513 & 2.909 & 0.163 & 0.568 \\
ROA & 0.132 & 0.102 & 0.526 & 0.007 & 0.116 \\
\hline
\end{tabular}


Sumber: diolah

Selanjutnya, pemilihan pengujian regresi linier berganda untuk model 1 dan model 2 masingmasing menggunakan common effect model. Adapun ringkasan hasil pengujian adalah sebagai berikut:

\begin{tabular}{|c|c|c|c|c|c|c|c|c|}
\hline \multirow[b]{2}{*}{ Var. } & \multicolumn{3}{|c|}{ Model 1} & \multicolumn{5}{|c|}{ Model 2} \\
\hline & Coeff & $\mathrm{t}$-Stat & Prob. & & Coeff & $\mathrm{t}$-Stat & Prob. & \\
\hline $\mathrm{C}$ & 0.289 & 29.336 & 0.000 & $* * *$ & 0.267 & 14.510 & 0.000 & $* * *$ \\
\hline MULNAT & -0.030 & -1.912 & 0.030 & $* *$ & -0.097 & -1.520 & 0.067 & $*$ \\
\hline THAV & 0.052 & 2.910 & 0.002 & $* * *$ & 0.131 & 1.890 & 0.032 & $* *$ \\
\hline $\mathrm{KI}$ & & & & & 0.048 & 1.458 & 0.075 & $*$ \\
\hline MULNAT*KI & & & & & 0.090 & 0.917 & 0.181 & \\
\hline THAV*KI & & & & & -0.121 & -1.144 & 0.129 & \\
\hline $\mathrm{OCF}$ & -0.160 & -2.138 & 0.018 & $* *$ & -0.195 & -2.317 & 0.012 & $* *$ \\
\hline DER & -0.005 & -0.493 & 0.312 & & -0.002 & -0.192 & 0.424 & \\
\hline $\mathrm{ROA}$ & 0.024 & 0.263 & 0.396 & & 0.044 & 0.4214 & 0.337 & \\
\hline $\mathrm{R}^{2}$ & 0.231 & & & & 0.290 & & & \\
\hline Adj. $R^{2}$ & 0.164 & & & & 0.185 & & & \\
\hline F-stat. & 3.432 & & & & 2.763 & & & \\
\hline Prob(F-stat.) & 0.009 & & & & 0.012 & & & \\
\hline
\end{tabular}

Sumber: data diolah

Hasil pengujian hipotesis menunjukkan bahwa multinationality berpengaruh positif terhadap penghindaran pajak. Hasil pengujian ini sejalan dengan Sima (2018), dan Widodo et al. (2020), namun tidak sejalan dengan Falbo \& Firmansyah (2021). Perusahaan multinational yang memiliki lebih dari satu cabang di satu negara menunjukkan memiliki perencanaan pajak yang lebih baik. Perusahaan multinasional biasanya mendirikan anak cabang perusahaan di negara yang menurutnya sesuai dengan pangsa pasarnya. Penghindaran pajak dilakukan dengan manajer menggeser laba perusahaan untuk menghindari adanya biaya pajak yang tinggi di satu negara tertentu. Manajer dengan melalui aktivitas multinationality, menggeser labanya dari negara yang memiliki tarif pajak lebih besar ke negara cabangnya yang memiliki tarif pajak lebih rendah atau bahkan nol. Praktek penghindaran pajak dilakukan oleh perusahaan multinasional memiliki cabang yang banyak di luar negeri (Sima, 2018).

Sementara itu, hasil pengujian hipotesis menunjukkan bahwa tax haven berpengaruh negatif terhadap penghindaran pajak. Hasil pengujian ini sejalan dengan pengujian yang dilakukan oleh Widodo et al. (2020), namun tidak sejalan dengan Sima (2018), dan Wijaya \& Rahayu (2021). Hasil pengujian ini membuktikan bahwa perusahaan multinasional di Indonesia yang memiliki lebih banyak pihak berelasi di negara tax haven country lebih jarang untuk melakukan penghindaran pajak. Perusahaan multinasional mendapatkan penghematan dari pajak di mana pihak berelasinya lebih banyak di negara-negara tax haven country. Selain itu, perusahaan multinasional di Indonesia lebih memilih untuk tidak melakukan penghindaran pajak untuk mendapatkan manfaat terkait dengan pangsa pasar dan tenaga kerja yang lebih mudah (Aryotama \& Firmansyah, 2019). Manajer selaku agen memilih untuk membuka cabang di negara yang menurutnya merupakan pangsa pasar yang besar. Manajer lebih memikirkan keberlangsungan perusahaan di masa depan dibandingkan dengan penghematan pajak yang diakibatkan adanya 


\section{JURNALKU}

Volume 1 No. 3, September 2021

pengalihan keuntungan kepada perusahaan yang berelasinya di negara-negara yang memiliki tariff pajak yang lebih rendah.

Selanjutnya, komisaris independen tidak memiliki peran dalam memperlemah hubungan positif antara multinationality dan penghindaran pajak maupun hubungan positif tax haven dan penghindaran pajak. Hasil pengujian ini menunjukkan bhawa di Indonesia komisaris independen tidak terlalu memiliki kewenangan yang kuat dalam perusahaan multinasional. Dalam konteks tata kelola perusahaan, perusahaan multinasional biasanya memiliki sistem dan sumber daya yang lebih baik, sehingga implementasi tata kelola sudah dilakukan dengan baik. Oleh karena itu, penggunaan komisaris independen dalam perusahaan multinasional lebih bersifat memenuhi persyaratan administrasi otoritas pengawas pasar modal di Indonesia (Kusuma \& Firmansyah, 2018; Nugroho \& Firmansyah, 2018). Walaupun komisaris independen memiliki latar belakang pendidikan dan pengalaman di bidang keuangan dan akuntansi, aktivitas perencanaan pajak yang dilakukan perusahaan multionasional di Indonesia sesuai dengan kebijakan induk perusahaan perusahaan multinasional tersebut. Aktivitas terkait dengan multinationality yang tinggi maupun kantor cabang perusahaan multinasional di negara tax haven sudah bukan menjadi kewenangan komisaris independen lagi. Komisaris independen diduga hanya berperan untuk menurunkan penghindaran pajak terkait dengan aktivitas-aktivitas yang secara langsung dilakukan oleh perusahaan domestik di Indonesia, namun tidak untuk aktivitas-aktivitas terkait dengan penghindaran pajak dengan melakukan income shifting ke cabang perusahaan multinasional di negara lain. Selain itu, kewenangan income shifting mungkin bukan diputuskan oleh manajemen perusahaan yang beroperasi di Indonesia, namun kebijakan pimpinan di perusahaan induk baik yang ada di Indonesia maupun yang ada di luar Indonesia.

\section{PENUTUP \\ Simpulan}

Aktivitas penghindaran pajak perusahaan multinasional dipengaruhi dengan aktivitas multinationality, namun tindakan tersebut tidak didukung dengan perusahaan berelasi di luar negeri yang termasuk dalam kategori tax haven country. Selain itu, penelitian ini juga menemukan bahwa peran komisaris independen dalam mendisiplinkan tindakan manajer dalam melakukan penghindaran pajak kurang optimal pada perusahaan-perusahaan multinasional. Penempatan komisaris independen diduga hanya untuk memenuhi syarat administrasi yang diatur oleh otoritas pengawas pasar modal di Indonesia.

\section{Saran}

Penelitian ini hanya menggunakan sampel pada perusahaan multinasional sektor industri barang konsumsi sehingga penelitian ini masih belum mewakili seluruh perusahaan multinasional yang terdaftar di Bursa Efek Indonesia. Selain itu, penelitian yang dilakukan hanya dengan menggunakan Laporan Keuangan pada periode tahun 2017-2019. Penelitian selanjutnya dapat menggunakan perusahaan dengan sektor yang lebih banyak dan horizon waktu yang lebih panjang untuk mendapatkan hasil yang lebih baik. Penelitian selanjutnya juga dapat menggunakan proksi penghindaran pajak selain ETR untuk membandingkan hasil pengujiannya dengan penelitian ini.

Penelitian ini menunjukkan bahwa otoritas pengawas pasar modal perlu meningkatkan peran komisaris independen pada perusahaan yang listed di Bursa Efek Indonesia baik perusahaan domestik maupun perusahaan multinasional yang bertujuan untuk meningkatkan perlindungan investor di pasar modal Indonesia. Selain itu, otoritas pengawas pasar modal perlu melakukan koordinasi dengan otoritas perpajakan di Indonesia terkait dengan aktivitas-aktivitas penghindaran pajak yang dapat merugikan kepentingan investor maupun kepentingan pemerintah. 


\section{DAFTAR PUSTAKA}

Andawiyah, A., Subeki, A., \& Hakiki, A. (2019). Pengaruh thin capitalization terhadap penghindaran pajak perusahaan indeks saham syariah Indonesia. AKUNTABILITAS: Jurnal Penelitian Dan Pengembangan Akuntansi, 13(1), 49-68. https://doi.org/10.29259/ja.v13i1.9342

Arham, A., Firmansyah, A., Nor, A. M. E., \& Vito, B. (2020). A bibliographic study on tax avoidance research in Indonesia. International Journal of Psychosocial Rehabilitation, 24(7), 9526-9554. https://www.psychosocial.com/article/PR270956/19446/

Armstrong, C. S., Blouin, J. L., Jagolinzer, A. D., \& Larcker, D. F. (2015). Corporate governance, incentives, and tax avoidance. Journal of Accounting and Economics, 60(1), 1-17. https://doi.org/10.1016/j.jacceco.2015.02.003

Aryotama, P., \& Firmansyah, A. (2019). The effect of corporate diversification, customer concentration on tax avoidance in Indonesia. Jurnal Akuntansi Dan Bisnis, 19(2), 117-125. https://doi.org/10.20961/jab.v19i2.475

Badan Pusat Statistik. (2021). Realisasi Pendapatan Negara (Milyar Rupiah), 2019-2021. https://www.bps.go.id/indicator/13/1070/1/realisasi-pendapatan-negara.html

Chen, S., Chen, X., Cheng, Q., \& Shevlin, T. (2010). Are family firms more tax aggressive than non-family firms? Journal of Financial Economics, 95(1), 41-61. https://doi.org/10.1016/j.jfineco.2009.02.003

Damayanti, H. H., \& Prastiwi, D. (2017). Peran OECD dalam meminimalisasi upaya tax agresiveness pada perusahaan multinationaly. Jurnal Akuntansi Multiparadigma (JAMAL), 8(1), 79-89. https://doi.org/10.18202/jamal.2017.04.7041

Desai, M. A., \& Dharmapala, D. (2006). Corporate tax avoidance and high-powered incentives. Journal of Financial Economics, 79(1), 145-179. https://doi.org/10.1016/j.jfineco.2005.02.002

DTCC. (2019). Ini peringkat negara suaka pajak versi tax justice networkarmful tax competition: an emerging global issue. https://news.ddtc.co.id/ini-peringkat-negara-suaka-pajak-versi-taxjustice-network-16030

Dwiyanti, I. A. I., \& Jati, I. K. (2019). Pengaruh profitabilitas, capital intensity, dan inventory intensity pada penghindaran pajak. E-Jurnal Akuntansi, 27(3), 2293-2321. https://doi.org/10.24843/EJA.2019.v27.i03.p24

Eksandy, A. (2017). Pengaruh komisaris independen, komite audit, dan kualitas audit terhadap penghindaran pajak (tax avoidance). COMPETITIVE Jurnal Akuntansi Dan Keuangan, 1(1), 1. https://doi.org/10.31000/competitive.v1i1.96

Fadhila, Z. R., \& Handayani, R. S. (2019). Tax amnesty effect on tax avoidance and its consequences on firm value (empirical study on companies in Indonesia stock exchange). Jurnal Dinamika Akuntansi, 11(1), 34-47. https://doi.org/10.15294/jda.v11i1.19264

Falbo, T. D., \& Firmansyah, A. (2021). Penghindaran pajak di Indonesia: multinationality dan manajemen laba. Bisnis-Net Jurnal Ekonomi Dan Bisnis, 4(1), 94-110. https://doi.org/10.46576/bn.v4i1.1325

Febrantara, D. (2021). SUAKA pajak ( tax haven) adalah istilah untuk menggambarkan suatu negara/yurisdiksi yang menjadi 'tempat berlindung' bagi para wajib pajak (WP). Di. https://news.ddtc.co.id/melihat-data-terkini-tax-haven-20207

Firmansyah, A., Jadi, P. H., \& Sukarno, R. S. (2021). Bagaimana respon investor terhadap kepemilikan saham oleh CEO? Jurnal Online Insan Akuntan, 4(1), 15-28. https://ejournal- 


\section{JURNALKU}

Volume 1 No. 3, September 2021

binainsani.ac.id/index.php/JOIA/article/view/1476

Firmansyah, A., Pamungkas, P. A., \& Zainuddin, F. M. (2021). Does corporate governance increase related party transaction disclosure in Indonesia? EAJ (Economic and Accounting Journal), 4(1), 1. https://doi.org/10.32493/eaj.v4i1.y2021.p1-12

Firmansyah, A., \& Triastie, G. A. (2020). The role of corporate governance in emerging market: Tax avoidance, corporate social responsibility disclosures, risk disclosures, and investment efficiency. Journal of Governance and Regulation, 9(3), 8-26. https://doi.org/10.22495/jgrv9i3art1

Fitria, G. N., \& Handayani, R. (2019). Tax avoidance: studi empiris pada perusahaan manufaktur sektor barang konsumsi di Indonesia. Monex : Journal Research Accounting Politeknik Tegal, 8(1), 251. https://doi.org/10.30591/monex.v8i1.1263

Hanlon, M., \& Heitzman, S. (2010). A review of tax research \$. Journal of Accounting and Economics, 50(2-3), 127-178. https://doi.org/10.1016/j.jacceco.2010.09.002

Hanlon, M., Mills, L., \& Slemrod, J. (2007). An empirical examination of corporate tax noncompliance. In Taxing Corporate Income in the 21st Century (Issue 1025). https://doi.org/10.1017/CBO9780511510823.014

Irawan, F., Kinanti, A., \& Suhendra, M. (2020). The impact of transfer pricing and earning management on tax avoidance. 12(3), 3203-3216. https://www.iratde.com/index.php/jtde/article/view/1229

Irawan, F., \& Safitri, W. K. F. (2021). Kajian proses penilaian kewajaran atas transaksi sewa pihak berelasi. Owner, 5(2), 278-288. https://doi.org/10.33395/owner.v5i2.491

Jensen, M. C., \& Meckling, W. H. (1976). Theory of the firm : managerial behavior, agency costs and ownership structure. Journal of Financial Economics, 3(4), 305-360.

Kemenkeu. (2020). Menkeu Paparkan Realisasi Penerimaan Perpajakan Hingga Agustus 2020. https://www.kemenkeu.go.id/publikasi/berita/menkeu-paparkan-realisasi-penerimaanperpajakan-hingga-agustus-2020/

kontan. (2020). Dirjen Pajak angkat bicara soal kerugian Rp 68,7 triliun dari penghindaran pajak. https://nasional.kontan.co.id/news/dirjen-pajak-angkat-bicara-soal-kerugian-rp-687-triliundari-penghindaran-pajak

Kusuma, C. A., \& Firmansyah, A. (2018). Manajemen laba, corporate governance, kualitas auditor eksternal dan agresivitas pajak. Jurnal Telaah Akuntansi Dan Bisnis, 8(1), 108-123. http://digilib.mercubuana.ac.id/manager/t!@file_artikel_abstrak/Isi_Artikel_331327738756. pdf

Laksono, D. G. D., \& Firmansyah, A. (2020). The role of managerial ability in indonesia: investment opportunity sets, environmental uncertainty, tax avoidance. Humanities \& Social Sciences Reviews, 8(4), 1305-1318. https://doi.org/10.18510/hssr.2020.84123

Nugroho, S. A., \& Firmansyah, A. (2018). Pengaruh financial distress, real earnings management dan corporate governance terhadap tax aggressiveness. Journal of Applied Business Administration, 1(2), 163-182. https://doi.org/10.30871/jaba.v1i2.616

OECD. (1998). Harmful tax competition: an emerging global issue. OECD. https://www.oecd.org/ctp/harmful/1904176.pdf

Pajakku. (2020). Dampak Penghindaran Pajak Indonesia Diperkirakan Rugi Rp 68,7 Triliun. https://www.pajakku.com/read/5fbf28b52ef363407e21ea80/Dampak-Penghindaran-PajakIndonesia-Diperkirakan-Rugi-Rp-687-Triliun

Prastiwi, D., \& Ratnasari, R. (2019). The inluence of thin capitalization and the executives' characteristics toward tax avoidance by manufacturers registered on ISE in 2011-2015. 


\section{JURNALKU}

Volume 1 No. 3, September 2021

AKRUAL: Jurnal Akuntansi, 10(2), 119. https://doi.org/10.26740/jaj.v10n2.p119-134

Purbowati, R., \& Yuliansari, S. (2019). Pengaruh manajemen laba dan corporate social responsibility terhadap tax avoidance. JAD: Jurnal Riset Akuntansi Dan Keuangan Dewantara, 2(2), 143-155. https://doi.org/10.26533/jad.v2i2.480

Puspitasari, D., Radita, F., \& Firmansyah, A. (2021). Penghindaran pajak di Indonesia: $\begin{array}{llll}\text { profitabilitas, leverage, } \quad \text { capital intensity. } & \text { 06(02), }\end{array}$ https://doi.org/10.48181/jratirtayasa.v6i2.10429

Richardson, G., Taylor, G., \& Lanis, R. (2013). The impact of board of director oversight characteristics on corporate tax aggressiveness: An empirical analysis. Journal of Accounting and Public Policy, 32(3), 68-88. https://doi.org/10.1016/j.jaccpubpol.2013.02.004

Sianipar, N. K. (2020). Determinan Penghindaran Pajak Dengan Ukuran Perusahaan Sebagai Variabel Moderasi [Universitas Sumatera Utara]. https://repositori.usu.ac.id/handle/123456789/29826

Sima, A. F. A. (2018). Analisis pengaruh multinasionalitas, pemanfaatan tax haven, thin capitalization dan ukuran perusahaan terhadap praktik penghindaran pajak pada perusahaan multinasional yang terdaftar di BEI [Universitas Sumatera Utara]. https://repositori.usu.ac.id/handle/123456789/9387

Sumunar, K. I., Jannah, L., \& Aulia, D. (2019). CEO overconfidence, tax avoidance, and education foundation. Jurnal Akuntansi \& Auditing Indonesia, 23(2), 99-105. https://doi.org/10.20885/jaai.vol23.iss2.art4

Taylor, G., \& Richardson, G. (2012). International corporate tax avoidance practices: evidence from Australian firms. International Journal of Accounting, 47(4), 469-496. https://doi.org/10.1016/j.intacc.2012.10.004

Watts, R. L., \& Zimmerman, J. L. (1990). Positive accounting theory: a ten year perspective. The Accounting Review, 65(1), 131-156. https://www.jstor.org/stable/247880

Widodo, L. L., Diana, N., \& Mawardi, M. C. (2020). Pengaruh multinasionalitas, good coorporate governance, tax haven, dan thin capitalization terhadap praktik penghindaran pajak pada perusahaan multinasional yang terdaftar di BEI periode tahun 2016-2018. Jurnal Ilmiah Riset Akuntansi, 09(6), 119-133. http://riset.unisma.ac.id/index.php/jra/article/view/6345

Wijaya, S., \& Rahayu, F. D. (2021). Pengaruh agresivitas transfer pricing, penggunaan negara lindung pajak, dan kepemilikan institusional terhadap penghindaran pajak. Jurnal Informasi, Perpajakan, Akuntansi, Dan Keuangan Publik, 16(2), 245. https://doi.org/10.25105/jipak.v16i2.9257 